\title{
A Meta-Analysis of Environmental Tradeoffs of Hydropower Dams in the Sekong, Sesan, and Srepok (3S) Rivers of the Lower Mekong Basin
}

\author{
Sarah E. Null 1,2,*iD, Ali Farshid 1, Gregory Goodrum 1, Curtis A. Gray 1,2 , Sapana Lohani 1,3, \\ Christina N. Morrisett ${ }^{1}$ (D), Liana Prudencio ${ }^{1}$ (D) and Ratha Sor ${ }^{1,4}{ }^{(D)}$ \\ 1 Department of Watershed Sciences, Utah State University, Logan, UT 84322, USA \\ farshid@aggiemail.usu.edu (A.F.); goodrum.greg@gmail.com (G.G.); curtis.gray@usu.edu (C.A.G.); \\ sapana.lohani@mso.umt.edu (S.L.); christina.morrisett@aggiemail.usu.edu (C.N.M.); \\ lianap566@gmail.com (L.P.); sor.ratha006@gmail.com (R.S.) \\ 2 Ecology Center, Utah State University, Logan, UT 84322, USA \\ 3 Global Water Center, University of Nevada, Reno, NV 89557, USA \\ 4 Graduate School, Chea Sim University of Kamchaymear, Phnom Penh 12300, Cambodia \\ * Correspondence: sarah.null@usu.edu
}

check for updates

Citation: Null, S.E.; Farshid, A.; Goodrum, G.; Gray, C.A.; Lohani, S.; Morrisett, C.N.; Prudencio, L.; Sor, R. A Meta-Analysis of Environmental Tradeoffs of Hydropower Dams in the Sekong, Sesan, and Srepok (3S) Rivers of the Lower Mekong Basin. Water 2021, 13, 63. https://doi.org/ $10.3390 /$ w13010063

Received: 29 October 2020 Accepted: 21 December 2020 Published: 30 December 2020

Publisher's Note: MDPI stays neutral with regard to jurisdictional clai$\mathrm{ms}$ in published maps and institutional affiliations.

Copyright: (C) 2020 by the authors. Licensee MDPI, Basel, Switzerland. This article is an open access article distributed under the terms and conditions of the Creative Commons Attribution (CC BY) license (https:// creativecommons.org/licenses/by/ $4.0 /)$.

\begin{abstract}
In Mekong riparian countries, hydropower development provides energy, but also threatens biodiversity, ecosystems, food security, and an unparalleled freshwater fishery. The Sekong, Sesan, and Srepok Rivers (3S Basin) are major tributaries to the Lower Mekong River (LMB), making up 10\% of the Mekong watershed but supporting nearly $40 \%$ of the fish species of the LMB. Forty-five dams have been built, are under construction, or are planned in the 3S Basin. We completed a meta-analysis of aquatic and riparian environmental losses from current, planned, and proposed hydropower dams in the $3 S$ and LMB using 46 papers and reports from the past three decades. Proposed mainstem Stung Treng and Sambor dams were not included in our analysis because Cambodia recently announced a moratorium on mainstem Mekong River dams. More than $50 \%$ of studies evaluated hydrologic change from dam development, 33\% quantified sediment alteration, and 30\% estimated fish production changes. Freshwater fish diversity, non-fish species, primary production, trophic ecology, and nutrient loading objectives were less commonly studied. We visualized human and environmental tradeoffs of 3S dams from the reviewed papers. Overall, Lower Sesan 2, the proposed Sekong Dam, and planned Lower Srepok 3A and Lower Sesan 3 have considerable environmental impacts. Tradeoff analyses should include environmental objectives by representing organisms, habitats, and ecosystems to quantify environmental costs of dam development and maintain the biodiversity and extraordinary freshwater fishery of the LMB.
\end{abstract}

Keywords: hydropower planning; fish; hydrologic alteration; biodiversity; 3S Basin; connectivity

\section{Introduction}

Planning and constructing hydropower dams have historically taken precedence over analyzing their environmental effects. While hydropower dams provide renewable energy, they also alter streamflow, trap sediment, fragment rivers, disrupt fish migrations and spawning, degrade ecosystems, and reduce biodiversity [1-3]. Large-scale hydropower projects are being considered in some of Earth's most biodiverse systems, including the Mekong, Amazon, and Congo Basins [1]. These projects will have cascading repercussions for local communities and food security [4]. The effects of dams on natural streamflow have been well studied [5]; however, quantifying the benefits of dam development and their environmental losses is needed to plan and operate hydropower dams efficiently, maintain food security for local communities, contain conflict, and maintain species, habitat, and ecosystems [6]. 
Unprecedented hydropower development in the 802,000 square kilometer $\left(\mathrm{km}^{2}\right)$ Mekong Basin embodies these challenges. Total hydropower potential in the Mekong Basin is estimated to be between 53,000 and 59,000 megawatts (MW) $[7,8]$. In the Lower Mekong Basin (LMB), which includes Myanmar, Thailand, Lao PDR, Cambodia, and Vietnam, 59 hydropower dams have been commissioned as of 2015 and installed capacity exceeds 10,000 MW. This capacity accounts for $35 \%$ of the potential hydropower capacity of the LMB [4]. The Sekong, Sesan, and Srepok Rivers (the 3S Basin) combine to form a major tributary to the Lower Mekong River and are a hotspot for hydropower dam development (Figure 1). Since 1990, 27 dams have been built and another 16 are planned (Table S1). The 27 existing dams provide installed capacity of over $4800 \mathrm{MW}$ and gross storage capacity of nearly $18,000 \mathrm{~m}^{3}$ [2]. Thailand is a major hydropower importer from Lao PDR, while Vietnam imports power from Cambodia and China [9]. Hydropower development may be a promising path for power-importing countries to generate energy and economic growth [10], although cost-benefit analyses suggest that power-exporting countries like Cambodia and Vietnam will lose ecosystem services and gain little in hydropower benefits [11].
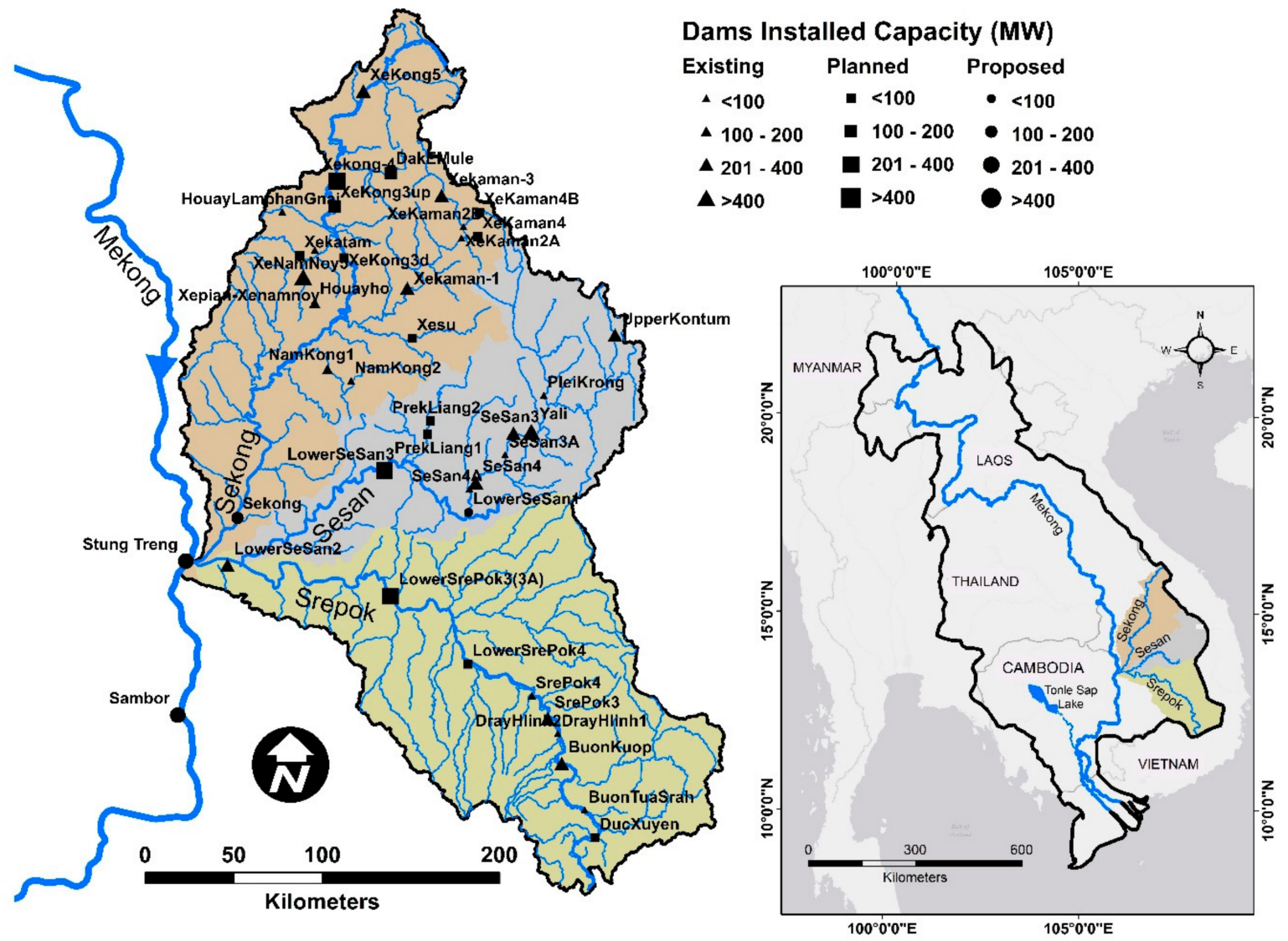

Figure 1. The Sekong, Sesan, and Srepok (3S) Basin with existing and planned hydropower dams.

The 35 Basin drains southern Lao PDR, Vietnam's Central Highlands, and northeastern Cambodia and has an outsized importance for Mekong River fisheries and ecology. The 35 Basin makes up $10 \%$ of the Mekong watershed's area, but provides up to $25 \%$ of streamflow and sediment load $[10,12]$. The $3 S$ Rivers historically provided critical habitat for megafishes and migratory fishes [13]. Fish are the primary source of protein in the LMB, with 65 million people dependent on fish for food security [4]. More than 2.2 million tonnes of freshwater fish are caught each year, valued at USD 3.6 to 6.5 billion (2009 dollars) as a first sale value [14], with retail markets approximately doubling value [15]. Dam 
construction in this basin therefore threatens freshwater biodiversity, a world-class fishery, and the health and livelihoods of many people dependent on fish for food.

Since early water resources systems models were developed more than 50 years ago, environmental objectives like natural streamflow, sediment transport, and aquatic habitat have become more emphasized worldwide and increasingly drive water management [16]. However, hydropower development in the LMB has been conducted on a project-by-project basis, rather than by creating optimal dam portfolios using systematic approaches that evaluate tradeoffs between hydropower benefits and environmental impacts [7]. Strategic assessments are now starting to be completed by researchers $[3,7,17]$. For example, recent research has shown that a different portfolio of dams could have equaled the current hydropower capacity in the Mekong Basin while more than doubling the current sediment supply to the delta [7]. Research that quantifies environmental losses with hydropower dam benefits is needed to identify dam sites, design details, and operating rules to minimize environmental impacts while generating hydropower.

We completed a meta-analysis to identify the aquatic and riparian environmental objectives considered in tradeoff analyses and to develop a comprehensive understanding of the benefits and environmental impacts of hydropower dams in the 3S Basin. We focused on the $3 S$ Basin and the Tonle Sap-Mekong-3S Basin (Figure 1), to holistically consider aquatic habitat connectivity, habitat quality, and movement between fish spawning and rearing habitats. A review of environmental tradeoffs of hydropower generation has yet to be completed for the Mekong Basin or other regions undergoing extensive dam development. Our research questions were (1) did the timing of hydropower dam research correspond with dam development, (2) what environmental objectives were quantified in existing tradeoff analyses, (3) what decision variables were used in published research to evaluate human benefits and environmental losses of dam development, (4) what data are available for future studies and systems models, and (5) what research gaps exist? This analysis synthesized understanding of environmental tradeoffs, identified current knowledge gaps, provided recommendations to reduce the redundancy of future research, and determined promising pathways for sustainable hydropower planning and decisionmaking in the $3 \mathrm{~S}$ Basin and LMB.

\section{Study Area and Methods}

\subsection{Study Area Background}

The Mekong River is the world's second-most biodiverse river, after the Amazon River, with the largest freshwater fishery [3]. The Mekong River has 877 identified freshwater fish species. Migration status is known for only $24 \%$ of those species, and of those, $87 \%$ are migratory [18]. At least 329 fish species, nearly $40 \%$ of the species identified in the LMB, utilize the $3 \mathrm{~S}$ Basin. This includes 89 migratory, 17 endemic, and 14 critically endangered fish species [19]. Many species depend on the extraordinary seasonal streamflow variability $[20,21]$, with a well-defined wet season from May to October followed by a dry season from November through April (Figure S1).

Dams have caused Lower Mekong streamflow to become more uniform throughout the year, as reservoirs are filled during the wet season and water is released through the dry season (Figure 2). A pronounced shift in Lower Mekong streamflow began by 2010, with more streamflow during the dry season and lower flows during the wet season than had been observed in the previous century [22]. Thus, the seasonal streamflow variability that a multitude of species rely on has been muted. The Mekong River historically transported approximately 160 million tons of suspended sediment per year. Dams trap sediment and sediment load is anticipated to decrease by $60-91 \%$ if hydropower is fully developed throughout the Mekong Basin [23,24]. As dams are built, habitat becomes fragmented longitudinally and latitudinally, blocking organism movement which is particularly problematic for megafishes and dozens of other species that migrate long distances to complete their life history [13,25] (Figure 2). Barbarossa et al. [26] estimated that longitudinal connectivity 
will be reduced by approximately $20 \%$ if all large dams are built that are currently under construction or planned.

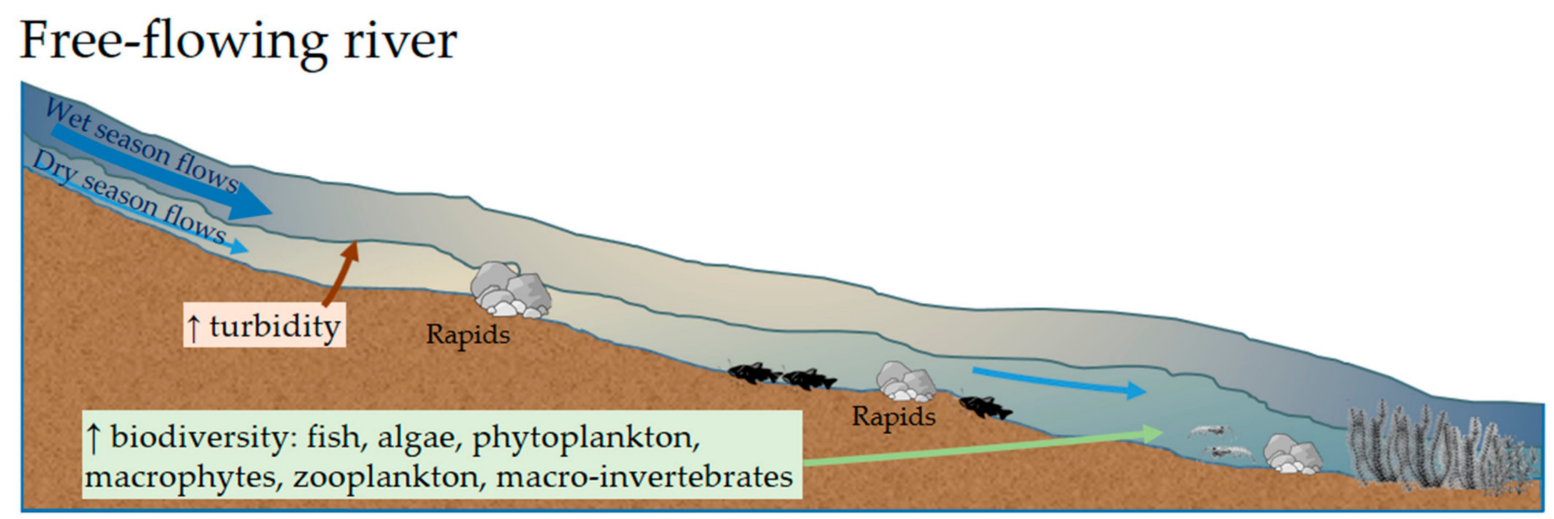

\section{Impounded river}

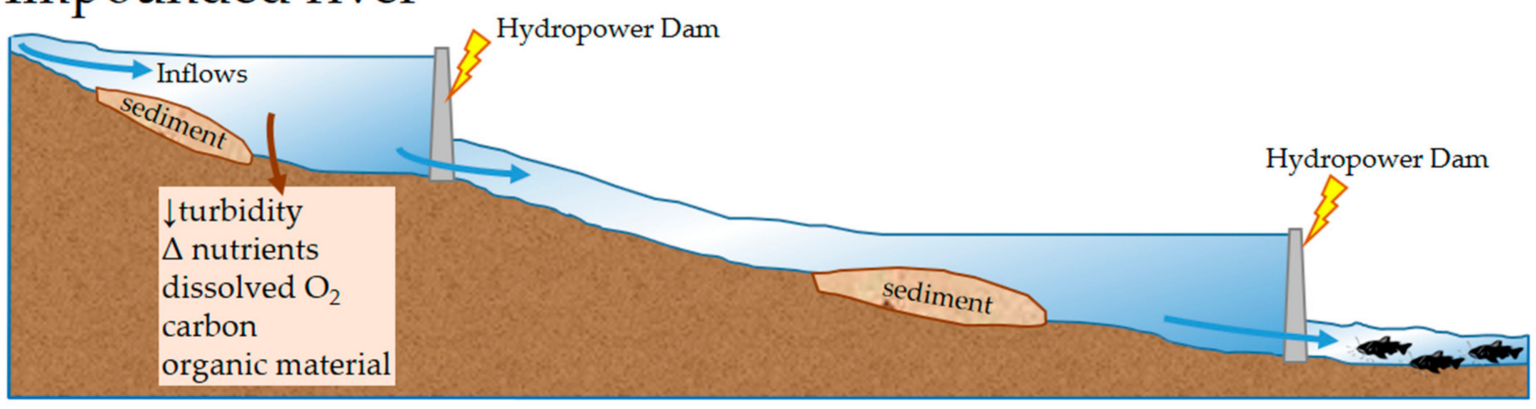

Figure 2. Conceptual model showing top: a free-flowing 3S river with a seasonal flood-pulse, high turbidity, high biodiversity, high productivity, and habitat that is connected longitudinally and laterally to floodplains and wetlands. Bottom: an impounded river with a cascade of hydropower dams that remove the seasonal flood-pulse, trap sediment, fragment and reduce habitat, block organism movement, and diminish biodiversity and productivity.

Migratory fishes generally move upstream to spawn in $3 S$ rivers with the wet season flood-pulse and migrate downstream to rear in Tonle Sap Lake or the Mekong Delta during the dry season [19,27] (Figure 1). Although dams have been proposed for the Sekong River, it currently remains undammed for much of its length (Figure S2). Cambodia announced a moratorium on building mainstem Mekong River Dams in 2020, putting construction of Stung Treng and Sambor Dams on indefinite hold [28]. Thus a fish passage corridor still exists between Tonle Sap Lake, the Mekong River, and the Sekong River. Lower Sesan 2, a 400 MW hydropower dam completed in 2018, blocks passage between the confluence of the Sesan and Srepok Rivers and the Mekong River.

\subsection{Literature Search}

We searched Google Scholar, Proquest, and Scopus databases for English-language primary or secondary literature with the keyword search shown in Table 1.

Table 1. Literature search teams and criteria.

\begin{tabular}{|c|c|c|c|c|c|c|}
\hline Mekong & AND & $\begin{array}{c}\text { tradeoff OR } \\
\text { trade-off }\end{array}$ & AND & $\begin{array}{c}\text { dam OR } \\
\text { hydropower }\end{array}$ & AND & $\begin{array}{c}\text { Sesan OR Se San OR Sê San OR Srepok OR } \\
\text { Sre Pok OR Serepôk OR Sekong OR Se } \\
\text { Kong OR Sê Kông OR 3S }\end{array}$ \\
\hline
\end{tabular}

We used different river names to find literature using the English, Lao, Vietnamese, and Cambodian spellings. All databases precede 1990, when the first dam was built in the $3 S$ Basin, and continue to the present. Our search was completed in March 2020. We re- 
viewed abstracts and included publications that focused on economic and aquatic/riparian environmental tradeoffs of current, existing, or proposed dams in the $3 \mathrm{~S}$ basin or Tonle Sap-Mekong River-3S Basin habitat corridor. We used a snowball method to include publications that focused on human-environmental tradeoffs in the LMB, but were not returned in our search results, typically because they did not include derivations of Sesan, Srepok, Sekong, or 3S in their title or keywords (e.g., [7,11,22]).

To remain within the scope of our study, we excluded publications on governance, transboundary conflicts, negotiation strategies, international cooperation, and water law. We removed review papers so that results were not double counted. We also removed papers that described, but did not quantify tradeoffs. When multiple versions of the same research existed as conference papers or book chapters, we included only the most recent version. Finally, we excluded papers that focused on effects of Chinese dams on downstream habitats as this was outside the scope of our study.

We classified papers by study system (e.g., 3S, Sesan Basin, LMB, Mekong River), the specific dams or hydropower futures studied, human objectives of dams (e.g., regulated streamflow, hydropower generation, spatial configuration of dams, water storage capacity, water supply, and economic cost), and environmental objectives of dams (e.g., hydrologic change, sediment load, fish production, fish diversity, aquatic/riparian habitat area, wetland area, longitudinal connectivity, primary production, non-fish biota, greenhouse gas emissions, and nutrients). Some researchers quantified environmental impacts when more dams were built, using metrics like number of dams. We included those papers in our analysis because installed generating capacity or similar human objectives of dams are widely available for the $3 S$ Basin and LMB $[2,12,29]$.

\subsection{Data Analysis}

\subsubsection{Dam Building and Publication Patterns}

We contextualized cumulative publication count with installed generating capacity $\left(10^{3} \mathrm{MW}\right)$ and gross storage $\left(10^{9} \mathrm{~m}^{3}\right)$ of dams constructed since 1990 . We summarized mean discharge $\left(\mathrm{m}^{3} \mathrm{~s}^{-1}\right)$, full water level $(\mathrm{m})$, gross storage $\left(10^{9} \mathrm{~m}^{3}\right)$, inundated area $\left(\mathrm{km}^{2}\right)$, installed generating capacity $\left(10^{3} \mathrm{MW}\right)$, and energy production $\left(\mathrm{GWh}\right.$ year $\left.{ }^{-1}\right)$ in Table S1 using data from $[12,17,30,31]$.

\subsubsection{Human and Environmental Objectives in Tradeoff Analyses}

We categorized human and environmental objectives in all studies, then mapped the frequency that specific human-environmental tradeoffs of hydropower dams were studied using the networkD3 package in R [32]. Some papers evaluated multiple human and environmental objectives, in which case each unique tradeoff was visualized as a separate link (Table S2). Human metrics could be easily interchanged because many studies provided dam information including hydropower generating capacity, reservoir capacity, and estimated or actual construction costs for dams [2,12,29,33]. We categorized papers and reports that used connectivity indices and freshwater health indices into the spatial configuration of dams category (e.g., [34-36]). Regulated streamflow was a human metric that researchers used to quantify environmental impacts like fish diversity (e.g., $[10,37]$ ), aquatic/riparian habitat area (e.g., [38,39]), or sediment load (e.g., [23,24]).

The hydrologic change environmental objective included all hydrologic and hydrodynamic impacts of dams (e.g., [38,40]). Sediment load research quantified changes in sediment transport and trapping from reservoirs (e.g., [2,24]). Fish production included surrogate variables like abundance, growth, biomass, and population (e.g., [3,41]). The fish diversity category included research where dam effects on specific fish species, guilds, assemblages, or families were quantified [10]. Aquatic/riparian habitat and wetland habitat studies measured areal change in aquatic and riparian habitats from dam development (e.g., [20,42]). Research on longitudinal connectivity examined fragmentation of river network connectivity (e.g., [26,34]). Primary production studies included analyzing sources of primary production during dry and wet seasons or quantifying gross primary production 
with dam development (e.g., [37]). The non-fish biota category included research on aquatic species aside from fish and included earthworms, shellfish, and turtles [43]. Greenhouse gas emissions studies analyzed emission fluxes from reservoirs [44]. Lastly, the nutrients category included research on nutrient loadings or transformations from dams [11].

\subsubsection{Tradeoff Meta-Analysis}

We visualized multi-objective human-environmental tradeoffs of each existing, planned, and proposed dam in the $3 \mathrm{~S}$ Basin using the plotly package in R [45]. This analysis used installed hydropower capacity, storage capacity, inundated reservoir area, and construction cost from Schmitt et al. [2], average change in migratory biomass from Ziv et al. [3], average trapped sediment load from Wild and Loucks [12], highest $\mathrm{CO}_{2}$ emissions per energy unit from Rasanen [44], and active storage to mean annual flow volume ratio from Piman et al. 2016 [17]. Our approach compared and visualized multiple human and environmental tradeoffs for individual $3 S$ dams, but did not consider marginal impacts as other dams were built. We did not include Stung Treng or Sambor Dams in our tradeoff analysis.

\subsubsection{S Habitat Fragmentation}

We summarized habitat connectivity in the 35 Basin using network components of rivers. Specifically, we used the Global River Classification (GloRiC) version 1.0 [46] in ArcGIS to calculate the number of disconnected stream components, average stream length per component, and maximum stream length of the largest component.

\section{Results}

\subsection{Dam Building and Publication Patterns}

Forty-six papers and reports met our literature search criteria. Thirteen papers focused on the Mekong Basin, 19 focused on LMB, and 14 focused on all or portions of the 3S Basin (Table S2). Dam planning and construction in the 3S Basin have clearly preceded published research (Figure 3). The first dam was completed in 1990 and the first scientific research on the environmental losses of hydropower dam construction was published in 2004. As a result, the apparent duration of dam construction in the 3S Basin (30 years) is currently almost twice that of the duration of environmental tradeoff research (16 years). However, when considering dam size, published environmental tradeoff research began only two years after the first large dam was completed. Environmental impact assessments were required for LMB dams, but were not returned in our literature review because they are often not publicly accessible. Thus, most research on the environmental effects of LMB dams have occurred after the fact and outside of the planning, permitting, and design process.

The first hydropower dam completed in the 3 S Basin was Dray Hlinh 1, which is among the smallest dams built in the region, with an installed capacity of $12 \mathrm{MW}$ and gross storage of 2.9 million cubic meters $\left(\mathrm{Mm}^{3}\right)$ (Table S1). Yali, the first large dam, was completed more than a decade later in 2002, with installed capacity of $720 \mathrm{MW}$ and gross storage of $1037 \mathrm{~mm}^{3}$ (Table S1). Cumulative hydropower capacity in the region increased markedly in years 2010, 2014, and 2018, as several large dams began operation (Figure 3). Published scientific research was slow to develop. From 2004 through 2011, only eight studies were published-with an average annual publication rate of one. The bulk of studies from our meta-analysis were published after $2011(80.4 \%)$ with an average annual publication rate of 4.1 from 2012 through March 2020.

Not shown in Figure 3 are two proposed Mekong mainstem dams between Tonle Sap Lake and the 3S Basin (Figure 1). Projected installed capacity of Stung Treng and Sambor Dams is $980 \mathrm{MW}$ and $2600 \mathrm{MW}$, respectively, and projected gross storage is $151 \mathrm{~mm}^{3}$ and $1450 \mathrm{~mm}^{3}$, respectively. In March 2020, Cambodia announced a moratorium on mainstem Mekong River dams until 2030, during which time Cambodia will consider alternative energy sources [28]. 

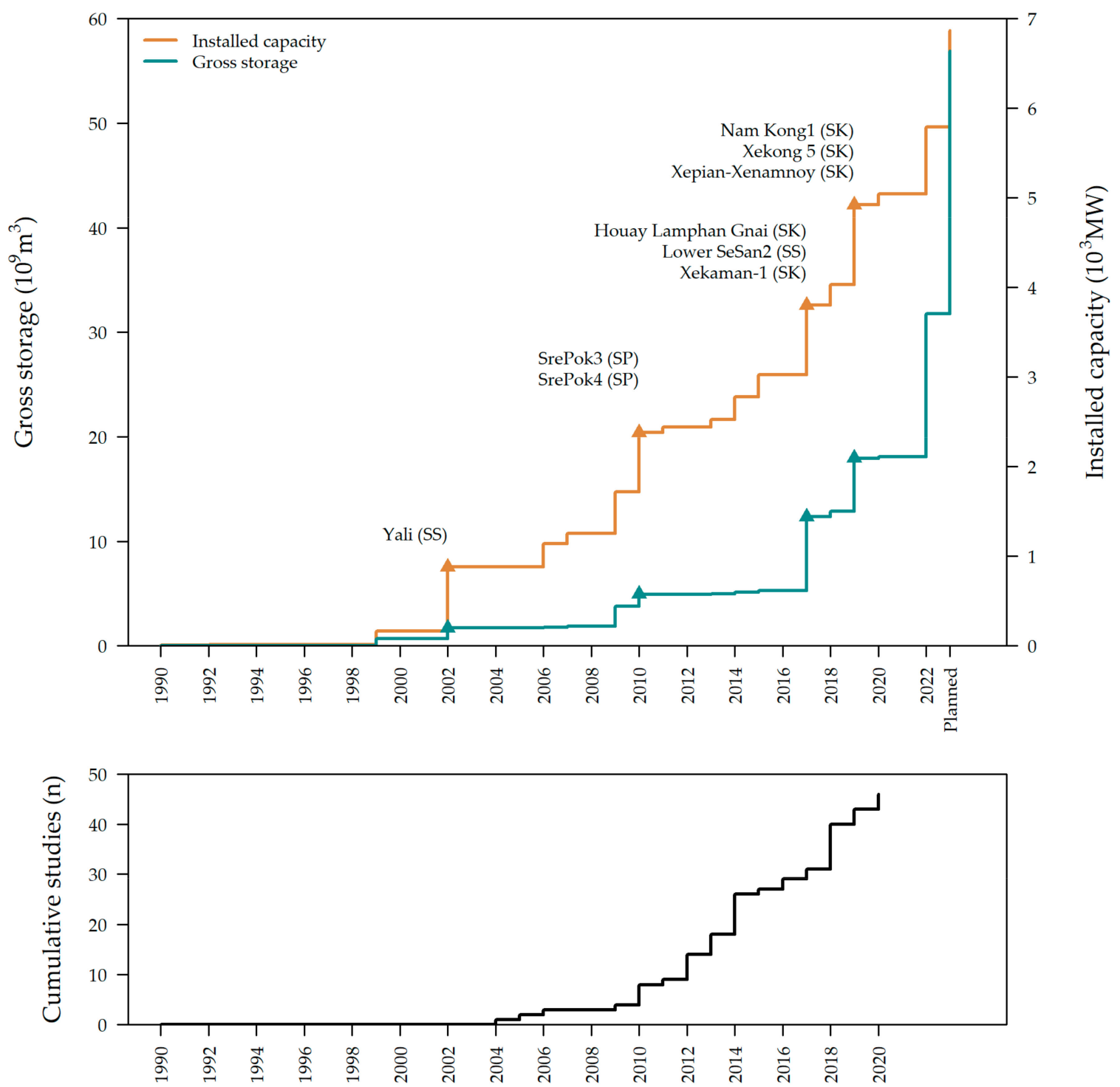

Figure 3. Gross storage and installed capacity of current and planned hydropower projects in the 3S Basin (top) with cumulative number of studies through time (bottom). SS is Sesan River, SP is Srepok River, and SK is Sekong River.

Each dam has been included in tradeoff analyses an average of 9 times, although Lower Sesan 2 has been evaluated nearly twice as often and Srepok 4A was studied just once (Figure 4). The proposed Sekong Dam, which could block remaining migratory passage to $3 S$ tributaries has rarely been studied. Ten studies evaluated no specific dams, rather they assessed environmental losses using regulated flows. Alternative dam futures based on scenarios developed by Mekong River Commission's second Basin Development Plan (BDP2) [33] and the International Center for Environmental Management (ICEM) [8] were used by many researchers. BDP2 included alternatives for the Definite Future (Lancang River and 26 tributary dams through 2015), Foreseeable Future (30 planned tributary dams and 11 mainstem dams through 2040), and Long-term Future (water resources development through 2050) [33]. ICEM alternatives include no mainstem dams, 11 mainstem dams, and 77 tributary dams within the Mekong Basin [8]. Twelve studies used iterations of those dam futures, although names or alternatives were slightly different so that it was not immediately transparent which specific dams were included in their tradeoff analyses. We classified those studies as having unavailable data about dams that were studied. 


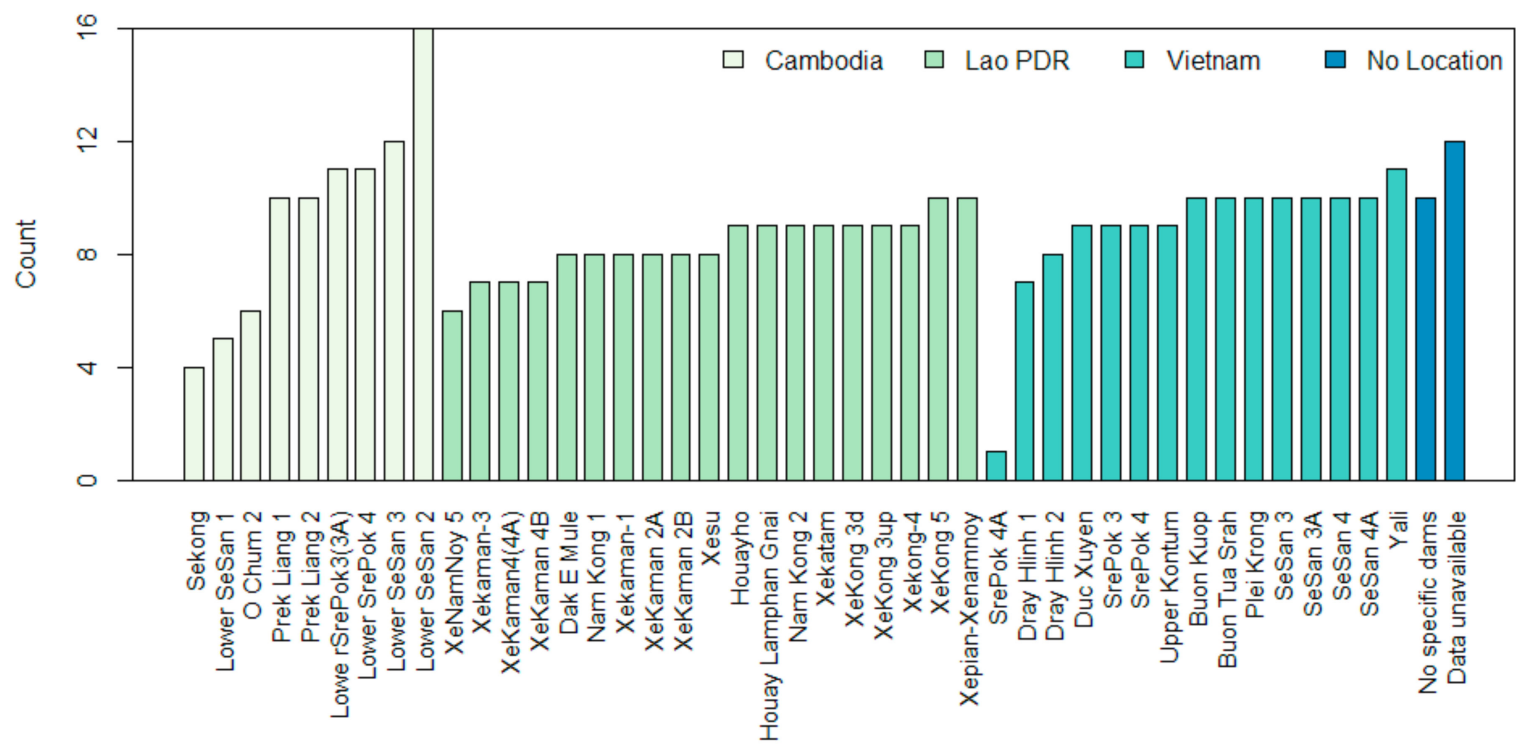

Figure 4. Number of times that 35 dams have been studied.

\subsection{Human and Environmental Objectives in Tradeoff Analyses}

Researchers disproportionately studied hydrologic and sediment environmental objectives (Figure 5, Table S2). Across all 46 studies, 24 (52\%) quantified hydrologic change, $15(33 \%)$ quantified impacts of dams on sediment load, $14(30 \%)$ quantified fish production, and 12 (26\%) studied aquatic or riparian habitat area. Of the 14 papers that focused exclusively on the 3 S Basin, 9 studies (64\%) quantified hydrologic change from dam development, while 5 studies (36\%) quantified dam impacts on sediment load. Fish production was commonly quantified in the Mekong Basin (14 studies, 30\%), but was uncommon in the 3S Basin (1 study, 7\%). Non-fish aquatic species were also quantified in only one study $(7 \%)$ of the $3 \mathrm{~S}$ Basin. Dam impacts on wetland area (6 studies, $13 \%)$, nutrient loading (4 studies, 9\%), primary production ( 3 studies, $7 \%$ ), and greenhouse gas emissions (1 study, $2 \%$ ) were rarely studied in the LMB and were not evaluated for the 35 Basin.

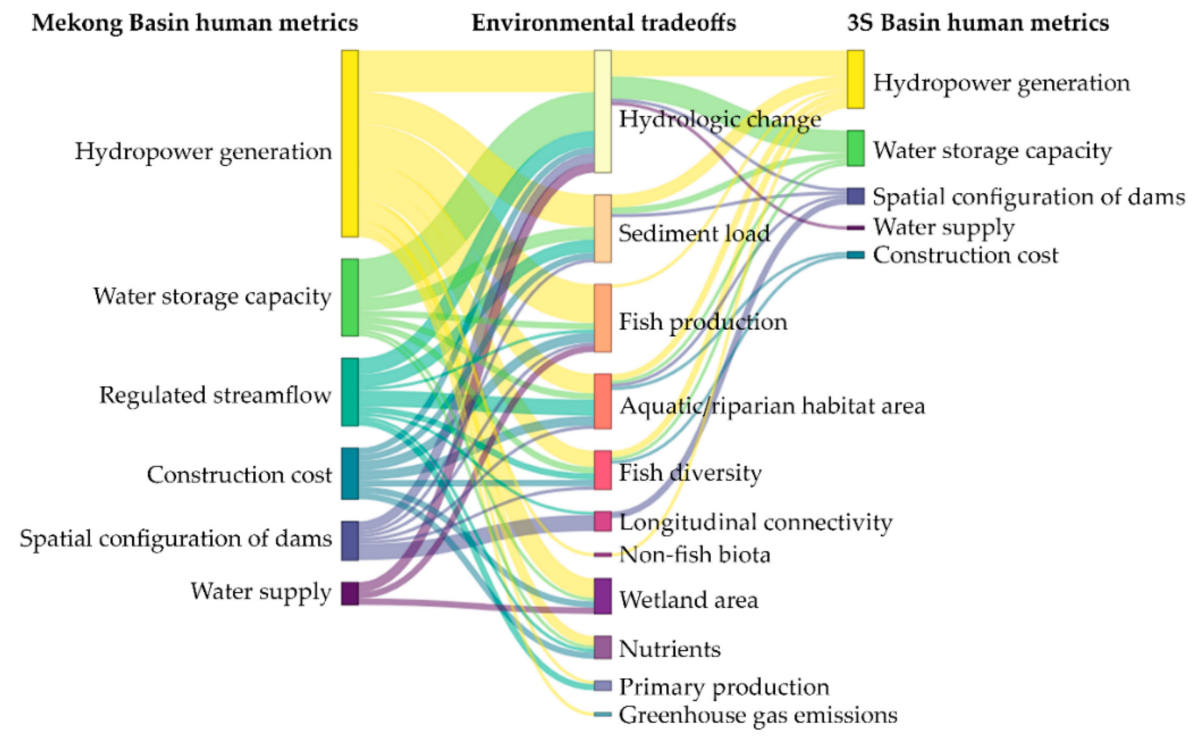

Figure 5. Human objectives of dams mapped to environmental losses that have been studied in the Mekong and 3S Basins. The width of the links is proportional to the frequency that tradeoffs have been studied. 
Physical processes are more straightforward to represent mathematically in models and were more commonly evaluated for the LMB and $3 S$ Basin. Studies that included at least one physical process objective, including hydrologic change, sediment load, habitat and wetland area, and longitudinal connectivity accounted for $89 \%$ of all studies and $100 \%$ of 3 S Basin studies. Ecological objectives are more difficult to incorporate into tradeoff analyses because relationships are often non-linear, poorly understood, or lack data to validate model fit [47]. Yet, $46 \%$ of all studies and $14 \%$ in the $3 S$ Basin included at least one ecological objective of fish production, fish diversity, non-fish biota, nutrient loading, primary production, or greenhouse gas emissions. This suggests that incorporating ecological relationships in hydropower dam decision-making is possible.

Most studies quantified human metrics of dams using hydropower generation and water storage capacity (Figure 5). Outside of the $3 \mathrm{~S}$ Basin, regulated streamflow was another common metric as a proxy for hydropower dam operation and was used in 12 studies (26\%). Across all studies, 25 (54\%) used hydropower generation as a human objective, while 14 studies (30\%) used reservoir storage capacity. In the 3S Basin, 12 studies (86\%) used hydropower generation as an objective and $8(57 \%)$ used reservoir storage capacity. Spatial configuration of dams, construction cost, and water supply were more rarely used to quantify human objectives of dams.

\subsection{Decision Variables in Tradeoff Analyses}

Decision variables are flexible and controllable parameters in models. Finding their value is the goal of modeling. In optimization modeling, decision variables determine the value of the objective function and in simulation modeling, decision variables are changed among model runs. Six papers analyzed all possible combinations of dams using multiobjective evolutionary algorithms or similar multi-objective approaches $[2,3,7,17,34,44]$. Of the papers that we reviewed, the most common decision variable was alternative future dam scenarios (Table S2). Future dam alternatives provided by BDP2 and ICEM proved invaluable for researchers to represent environmental impacts from streamflow changes due to hydropower dam construction. These alternatives were used in 18 studies that we reviewed (e.g., [11,12,35,42,48,49]). However, specific futures varied among studies, producing results that were not directly comparable. Furthermore, alternatives were often named similarly to BDP2 and ICEM alternatives, but names of specific dams were not listed, reducing the transparency of research (Figure 4). Alternative dam operations, design, and siting were decision variables that are increasingly used to quantify the environmental tradeoffs of hydropower dams in the 3S Basin and LMB [22,48,50-55]. These papers often had a small spatial extent, for example focusing on single dams or reaches, and complemented studies that evaluated alternative dam construction futures.

\subsection{Tradeoff Meta-Analysis}

Multi-objective tradeoffs were compared among $3 \mathrm{~S}$ dams (Figure 6) using eight human and environmental performance criteria. Each axis represents a unique objective with performance increasing toward the bottom of the figure and each line shows a $3 \mathrm{~S}$ dam. Performance was unavailable for some objectives, in which case performance was shown as points on axes for those objectives where data were available. Lines and points indicate where performance in one objective cannot be improved without degrading performance in other objectives. Lines with steep slopes between axes indicate conflict between objectives. The named red, orange, yellow, and green lines and points indicate dams with pronounced tradeoffs between human and environmental objectives. 


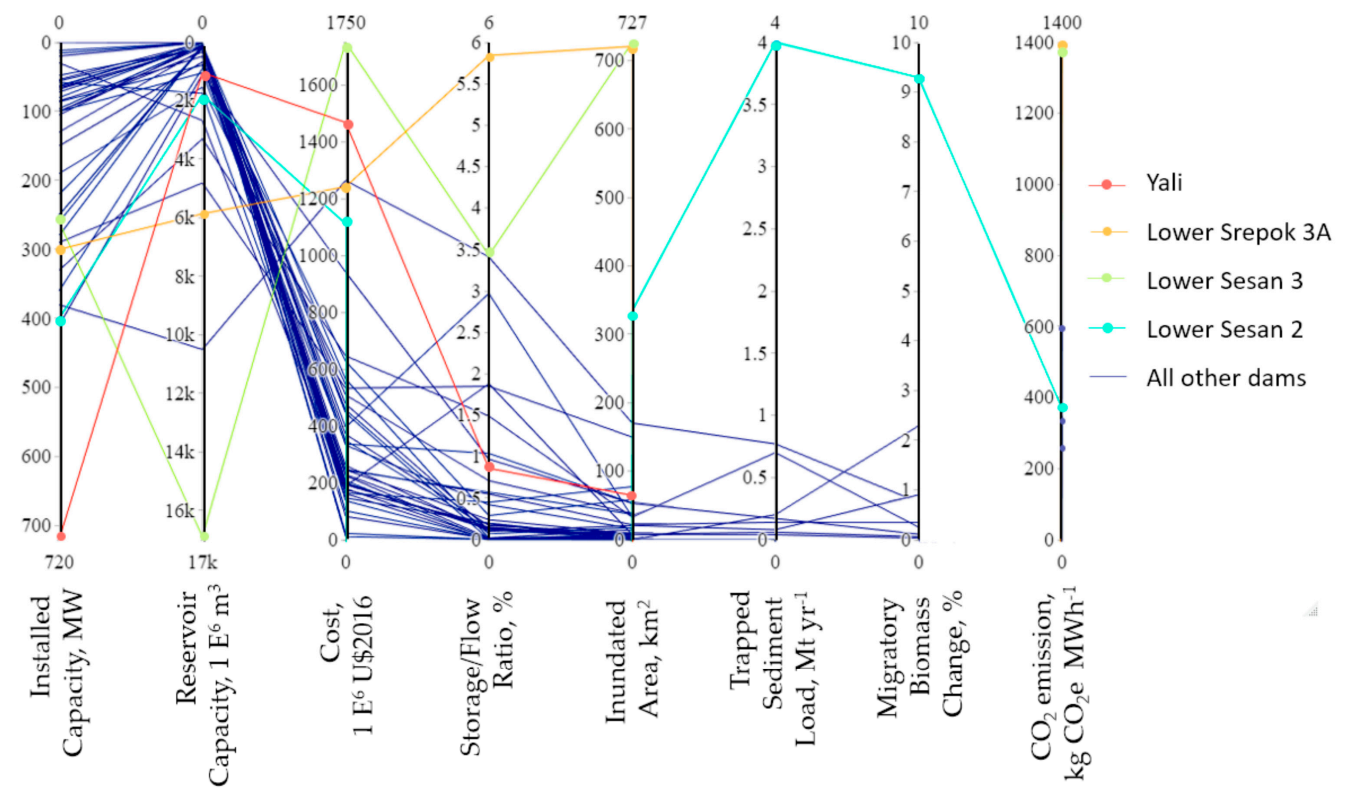

Figure 6. Parallel axis plot of tradeoffs among competing human and environmental objectives. Each axis represents a different objective with better performance at the bottom. Each line shows tradeoffs for different existing or planned dams. Environmental objectives are unavailable for some dams. Data for human objectives of installed capacity, storage capacity, and cost were from [2]. Environmental objectives and data sources include inundated area [2], Storage-flow ratio [17], average trapped sediment load [12], $\mathrm{CO}_{2} \mathrm{e}$ emissions per energy unit [44], and average change in migratory biomass [3].

In general, conflicts exist between installed hydropower capacity and environmental objectives of storage/flow ratio, inundated area, trapped sediment load, migratory fish biomass change, and $\mathrm{CO}_{2}$ e emissions (Figure 6). Smaller dams with less capacity to generate hydropower had less severe tradeoffs with environmental objectives, although this analysis did not represent marginal impacts as dams are built sequentially (Figure 6).

Yali Dam was the first large dam built in the 3S Basin with installed capacity of 720 MW (Table S1). It was completed in 2002 and has more generating capacity than all other existing, planned, and proposed dams with less environmental harmful changes to storage/flow ratio and inundated area. Lower Sesan 2, which was completed in 2018, trapped more sediment than other $3 \mathrm{~S}$ dams and was most harmful to migratory fish biomass. Planned Lower Sesan 3 dam would inundate the most area, which is a proxy for longitudinal and latitudinal habitat loss and fragmentation. Planned Lower Srepok 3A Dam would have the largest storage/flow ratio, a metric of flow alteration. Lower Sesan 3 and Lower Srepok $3 \mathrm{~A}$ are also anticipated to produce the highest $\mathrm{CO}_{2} \mathrm{e}$ emissions per energy unit. Notably, proposed Lower Srepok 3A and Lower Sesan 3 Dams have less generating capacity, but considerably larger reservoirs, than existing Yali and Lower Sesan 2 Dams. Large reservoirs correspond with inundated area, storage/flow ratio, and $\mathrm{CO}_{2} \mathrm{e}$ emissions environmental tradeoffs.

\subsection{Habitat Fragmentation}

Prior to dam construction, 10,331 km of streams were accessible to migratory fishes in the Sekong Basin (Figure 7). If Sekong Dam is built, it would disconnect the 35 Basin from the mainstem Mekong River and Tonle Sap Lake, blocking $4784 \mathrm{~km}$ of habitat to the next existing and planned dams upstream (pink stream segments in Figure 7). This segment is the largest section of connected habitat and represents $46 \%$ of pre-dam stream length. Nineteen dams have been built or are planned upstream of the proposed Sekong Dam, resulting in 32 disconnected stream segments, with an average stream length of $323 \mathrm{~km}$ ( $3 \%$ of the pre-dam length). 


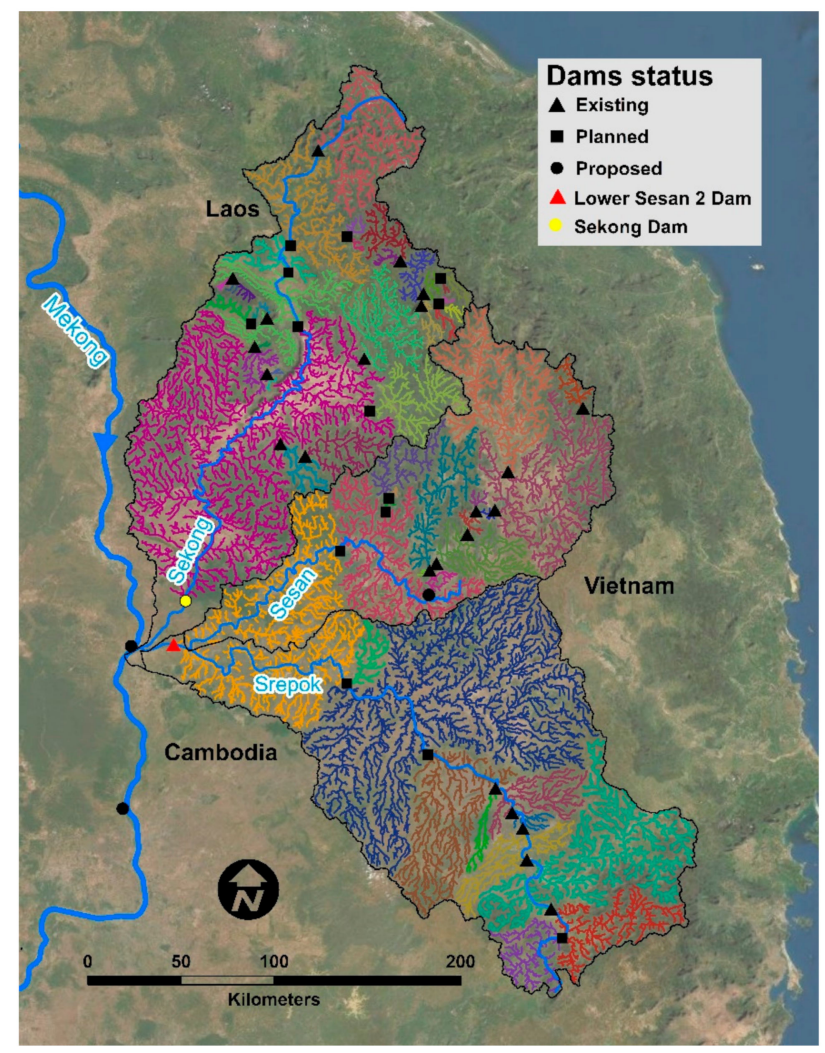

Figure 7. Fragmented stream segments, shown with different colors, in the 3S Basin from existing, planned, and proposed dams.

A total length of 18,701 km of streams exist upstream of Lower Sesan 2 Dam (Figure 7). Construction of Lower Sesan 2 disconnected the Sesan and Srepok Rivers with the Mekong River and blocked $2535 \mathrm{~km}$ of stream segments to the next upstream dams (orange segments in Figure 7). There are 20 existing and planned dams upstream of Lower Sesan 2, which separate these basins into 25 disconnected segments, with an average of stream length of $748 \mathrm{~km}$, and a maximum length of $5035 \mathrm{~km}$. Thus, the average connected stream length is $4 \%$ of the original pre-dam length, and the longest intact stream length that is $27 \%$ of the original pre-dam length.

\section{Discussion}

We analyzed English-language published and gray literature that quantified human and environmental tradeoffs of hydropower dam development in the 3S Basin and Tonle Sap-Mekong-Sekong corridor. Dam planning and construction has been ongoing since 1990, and preceded research in this region. Environmental impact assessments were required for all dams in the LMB, but these reports were not returned in our search and are typically not publicly available. In general, the environmental impact assessments required for LMB dam planning were often incomplete, did not account for cumulative impacts of dams, nor did they consider alternative locations, operations, or technologies [56]. Generally, there was more emphasis on energy development than on environmental impacts. However, studies that evaluate environmental losses from hydropower dams have recently increased, with an average of 4.1 papers per year since 2012. Hydrologic change, sediment load, fish production, and aquatic/riparian habitat area were the most common environmental objectives studied. Fewer researchers analyzed dam development effects on fish diversity, longitudinal connectivity, non-fish aquatic species, wetland habitat area, nutrient loading, primary production, or greenhouse gas emissions, although those environmental losses were quantified in at least one paper or report. Better representing ecological impacts of 
hydropower dams is needed to fully understand their environmental tradeoffs and this is an area that merits research and innovation.

Our meta-analysis highlighted dams with conflicts between human and environmental objectives. Lower Sesan 2 had considerable tradeoffs with migratory fish biomass [3] and trapped sediment [12]. Planned Lower Sesan 3 would have substantial $\mathrm{CO}_{2} \mathrm{e}$ emissions [44] and inundate the most area [2]. Planned Lower Srepok $3 \mathrm{~A}$ would have the highest $\mathrm{CO}_{2} \mathrm{e}$ emissions [44] and a large storage/flow ratio [17]. Since Lower Sesan 2 has blocked fish passage for at least 85 migratory fish species to the Sesan and Srepok Rivers [57], maintaining connectivity and passage between Tonle Sap, the Mekong River, and the lower Sekong River takes on greater importance. The proposed Sekong Dam should be avoided because it would block longitudinal connectivity [36] and migratory fish passage for at least 64 species between spawning and rearing habitats [13,57] (Figure 8). Cambodia's ten-year moratorium (2020-2030) on building mainstem Mekong River dams highlights the value of fish passage and the uncertainty of dam building when other energy sources may be economically competitive or less environmentally damaging. Foregoing the proposed Sekong, Sambor, and Stung Treng dams would maintain one free-flowing tributary for much of its length, while providing hydropower from dam cascades in other tributaries. Giving up Sekong Dam supports research showing that building dams in the downstream reaches of tributaries should be avoided [47], and that managing rivers for either human or environmental benefits can provide greater economic and environmental benefits than managing for both human and environmental benefits simultaneously on multiple rivers $[6,58]$.

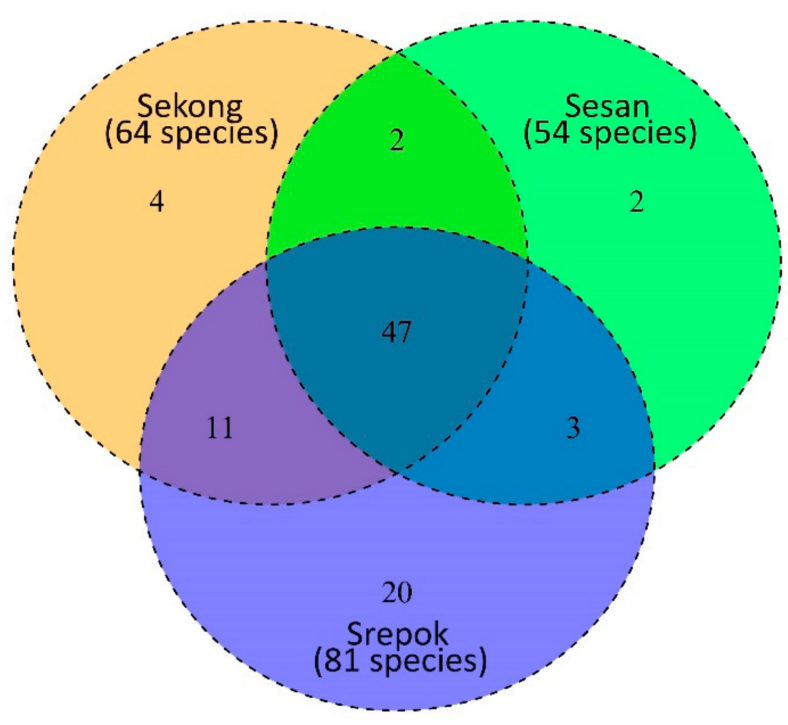

Figure 8. Overlap among the 89 migratory fish species that use 35 rivers. The number of species in brackets indicates the total number of migratory fish species that utilize each watershed. Data from [57].

A handful of papers made a compelling case for decision-making that better recognized environmental impacts in LMB because they creatively incorporated ecological objectives of rivers $[3,11,22]$ or because they provided strategic sequencing of dam development [7]. Ziv et al. [3] coupled a simple model of fish population and biodiversity to evaluate change in migratory fish biomass with added hydropower generation across multiple dams. Their approach provided an elegant example of incorporating ecological objectives into decision-making. Intralawan et al. [11] completed an economic tradeoff analysis between hydropower generation and ecosystem services in LMB and determined the total net economic impact of mainstem and tributary dams is negative USD 7.3 billion when costs to reservoir fisheries, aquaculture, capture fisheries, wetlands, cultural services, sediment, and nutrients are included. This contrasted MRC's BDP2 Basin Development 
Plan which estimated a positive economic impact of USD 33.4 billion by omitting most environmental objectives [33]. Wild et al. [22] evaluated alternative siting, design, and operations for Cambodia's proposed Sambor Dam to maximize energy and larval fish passage. The authors recommended addressing ecological concerns prior to and on equal footing as energy benefits. A short while later, Cambodia announced a moratorium on building Sambor and Stung Treng mainstem dams [28]. Finally, Schmitt et al. [7] optimized the sequence of dam construction to minimize sediment trapping from hydropower dams in the LMB. The authors showed that the same hydropower benefits could have been generated while trapping approximately half the sediment than is currently trapped behind dams and prioritized future dam construction to maximize hydropower generation and minimize sediment trapping.

\subsection{Redundancy of Hydrologic Modeling and Future Recommendations}

The redundancy of hydrologic and hydraulic modeling in the LMB was notable. Three modeling review papers have been written [59-61], with Jensen [60] describing the Mekong Basin as "flooded with models". Yet, modeled streamflow data were rarely publicly available or provided with supplemental information of publications. Streamflow models and data developed in 2012 are available from Mekong Flows (http:/ / www.mekongflows.com) for 1986-2006 baseline conditions, and multiple dam futures, operations, and climate change alternatives $[17,20,38-40,48,62,63]$. Although more than half of the studies that we evaluated quantified hydrologic changes from dam development, we were unable to locate other shared models or simulated streamflow for alternative hydropower dam futures. Hydroshare's Mekong data and model sharing platform (https:/ / www.mekongwater.org/) and the Mekong River Commission's data portal (https:/ / portal.mrcmekong.org/home) returned no publicly discoverable modeled hydrology data for alternative dam futures. Sharing models and data improves the reproducibility of research [64] and reduces research redundancy, which is imperative in the Mekong Basin, where non-streamflow relationships with dam development are beginning to be quantified. Evaluating ecosystem response to dam development is recommended for ecological sustainability of multi-objective hydropower operation [65].

The Mekong River Commission has developed basin-wide dam development scenarios for baseline, definite future dam development, year 2030 foreseeable future dam development, and year 2060 long-term future dam development [33]. These scenarios are routinely incorporated into current research (e.g., $[11,12,35,42,48,49])$, highlighting the importance of defined dam future alternatives for research and decision-making. An opportunity exists for the Mekong River Commission to provide modeled hydrologic and hydraulic data to support decision-making, reduce model and research redundancy, and harmonize model assumptions. A blueprint for success exists from the Intergovernmental Panel on Climate Change, which has developed compatible datasets to understand anticipated climate impacts and promising adaptations [66]. The Mekong River Commission and other research funders could also require that data and models are shared publicly, as is required by a growing number of publishers [67] to ensure that data and results are available and transparent for decision-makers.

\subsection{History and Future of Tradeoff Analyses in Dam Planning and Operations}

Environmental impacts were not quantified in dam-building eras in the United States or Europe [68,69], although environmental movements followed dam-building when costs of degraded systems were better quantified. Environmental regulations have since often steered water management [70-72]. Given current understanding of aquatic systems and the value they provide, water projects in the United States and Europe would be sited, designed, and operated differently if they were built today [73]. In fact, more dams are now removed in North America and Europe than are built [69].

Overestimating hydropower benefits while ignoring environmental degradation from dam development is costly. This is already clear in the 3S Basin and LMB. Evidence has emerged that hydropower benefits have been overestimated [74,75]. In Lao PDR, 
hydropower production costs $20 \%$ more than anticipated during dry periods when thermal power is required to meet energy demand. During wet years, limited transmission line capacity results in unused hydropower [76]. As mentioned above, including costs of lost capture fisheries, sediment transport, and nutrients in the cost-benefit analysis for LMB dams resulted in a projected total economic impact that was negative USD 7.3 billion [11], whereas BDP2 estimated a positive economic impact of USD 33.4 billion without fully quantifying the environmental costs [33].

Environmental degradation in the LMB is already occurring from hydropower dam operations which increase dry season streamflow and reduce the flood-pulse [22]. Further repercussions are anticipated. For example, hydrologic alteration threatens flooded forest habitats surrounding Tonle Sap Lake, including RAMSAR wetlands and a UNESCO biosphere reserve $[10,77]$. The productivity of the world's largest inland fishery at Tonle Sap Lake is in decline [78,79], jeopardizing food security for 65 million people [4]. Water quality has been impaired in the Mekong River downstream of the 3S Basin, including Tonle Sap Lake and the Mekong Delta [80,81], and sediment trapping in reservoirs has endangered agricultural production and increased the frequency of seawater intrusion in Vietnam's Mekong Delta (MRC 2005). The extinction of rare and endangered species like the Mekong giant catfish and the Irrawaddy dolphin are probable if environmental and ecological tradeoffs of hydropower development are ignored [82,83].

At a broader scale, dam building also affects terrestrial systems and society. For example, dam building contributes to deforestation as forests are cleared around reservoirs, roads and other infrastructure are built, settlements form, and forest is converted to agriculture [84]. These changes are coupled with climate warming, which is anticipated to increase drought frequency of intensity in the 3 S Basin and LMB [85]. Dam building and extreme streamflow variability pose natural hazard risk to society by reducing agriculture, employment opportunities, gross domestic product, and food security in the LMB $[86,87]$.

Quantifying environmental impacts is an opportunity for dam planning that has the potential to preserve aquatic species, habitats, ecosystems, ecosystem services, human livelihoods, and food security while providing hydropower. Hydropower dams are one of many substantial changes anticipated in the $3 S$ Basin and LMB. Other threats include ongoing deforestation, urbanization, and climate change [84,88]. Ignoring the environmental costs of hydropower development in the 3S Basin and LMB is likely to be costly. This paper and the existing body of research provides broad support to more fully consider the environmental losses and costs of hydropower dams in the 35 Basin to guide sustainable hydropower decision-making. Quantifying environmental losses from hydropower development, especially ecological losses, is of utmost importance to maintain valuable ecosystems and migratory corridors, and avoid overestimating the net benefit of hydropower development.

Supplementary Materials: The following are available online at https:/ /www.mdpi.com/2073-4 441/13/1/63/s1, Figure S1: Maximum, average, and minimum streamflow at Chatangoy (Sekong River) and Ban Kamphun (Sesan and Srepok Rivers) gaging stations from 1960 to 2002, Figure S2: Longitudinal profile of existing, planned, and proposed dams on mainstem Sekong, Sesan, and Srepok Rivers, Table S1: Dams in the 3S Basin and their attributes, Table S2: Papers included in review, study system, human and environmental objectives, and decision variables.

Author Contributions: Conceptualization, S.E.N.; methodology, S.E.N.; paper review, S.E.N., A.F., G.G., C.A.G., S.L., C.N.M., L.P.; formal analysis, S.E.N., A.F., G.G., C.A.G., S.L., C.N.M., L.P.; writingoriginal draft preparation, S.E.N.; writing-review and editing, S.E.N., A.F., G.G., C.A.G., S.L., C.N.M., L.P., R.S.; visualization, S.E.N., A.F., G.G., C.A.G., S.L., C.N.M., L.P., R.S.; supervision, S.E.N.; project administration, S.E.N.; funding acquisition, S.E.N. All authors have read and agreed to the published version of the manuscript.

Funding: Research was funded by United States Agency for International Development's “Wonders of the Mekong" Cooperative Agreement No: AID-OAA-A-16-00057. C.N.M. and L.P. received support from the National Science Foundation grant no. 1633756. 
Institutional Review Board Statement: Not applicable.

Informed Consent Statement: Not applicable.

Data Availability Statement: All data and code used in this study are available on the American and Mekong instances of Hydroshare [89,90].

Acknowledgments: We thank Zeb Hogan who provided feedback on an early version of this paper.

Conflicts of Interest: The authors declare no conflict of interest.

\section{References}

1. Winemiller, K.O.; McIntyre, P.B.; Castello, L.; Fluet-Chouinard, E.; Giarrizzo, T.; Nam, S.; Baird, I.G.; Darwall, W.; Lujan, N.K.; Harrison, I.; et al. Balancing hydropower and biodiversity in the Amazon, Congo, and Mekong. Science 2016, 351, 128-129. [PubMed]

2. Schmitt, R.J.P.; Bizzi, S.; Castelletti, A.; Kondolf, G.M. Improved trade-offs of hydropower and sand connectivity by strategic dam planning in the Mekong. Nat. Sustain. 2018, 1, 96-104.

3. Ziv, G.; Baran, E.; Nam, S.; Rodríguez-Iturbe, I.; Levin, S.A. Trading-off fish biodiversity, food security, and hydropower in the Mekong River Basin. Proc. Natl. Acad. Sci. USA 2012, 109, 5609-5614. [PubMed]

4. Mekong River Commission. State of the Basin Report 2018; Lao PDR: Vientiane, Laos, 2019.

5. Poff, N.L.; Allan, J.D.; Bain, M.B.; Karr, J.R.; Prestegaard, K.L.; Richter, B.D.; Sparks, R.E.; Stromberg, J.C. The Natural Flow Regime. Bioscience 1997, 47, 769-784.

6. Null, S.E.; Olivares, M.A.; Cordera, F.; Lund, J.R. Pareto Optimality and Compromise for Environmental Water Management; American Geophysical Union: Washington, DC, USA, 2020; Available online: https://search.proquest.com/docview/2451147242?pqorigsite $=$ gscholar\&fromopenview $=$ true (accessed on 14 October 2020).

7. Schmitt, R.J.P.; Bizzi, S.; Castelletti, A.; Opperman, J.J.; Kondolf, G.M. Planning dam portfolios for low sediment trapping shows limits for sustainable hydropower in the Mekong. Sci. Adv. 2019, 5, eaaw2175.

8. ICEM. MRC Strategic Environmental Assessment (SEA) of hydropower on the Mekong mainstream. Hanoi Viet Nam, ICEM, Aust. 2010. Available online: http:/ / www.mrcmekong.org/assets/Publications/Consultations/SEA-Hydropower/SEA-MainFinal-Report.pdf (accessed on 10 December 2020).

9. Hydropower Thematic Team and Multi-consult. Thematic Report on the Positive and Negative Impacts of Hydropower Development on the Social, Environmental, and Economic Conditions of the Lower Mekong River Basin. Prepared by Hydropower Thematic Team and Multi-consult. 2017. Available online: http://www.mrcmekong.org/assets/Publications/Council-Study/Council-study-ReportsThematic/Impacts-of-Hydropower-Development-29-December-2017.pdf (accessed on 10 December 2020).

10. Ngor, P.B.; Legendre, P.; Oberdorff, T.; Lek, S. Flow alterations by dams shaped fish assemblage dynamics in the complex Mekong-3S river system. Ecol. Indic. 2018, 88, 103-114.

11. Intralawan, A.; Wood, D.; Frankel, R.; Costanza, R.; Kubiszewski, I. Tradeoff analysis between electricity generation and ecosystem services in the Lower Mekong Basin. Ecosyst. Serv. 2018, 30, 27-35.

12. Wild, T.B.; Loucks, D.P. Managing flow, sediment, and hydropower regimes in the Sre Pok, Se San, and Se Kong Rivers of the Mekong basin. Water Resour. Res. 2014, 50, 5141-5157.

13. Campbell, T.; Pin, K.; Ngor, P.B.; Hogan, Z. Conserving Mekong Megafishes: Current Status and Critical Threats in Cambodia Water 2020, 12, 1820

14. Hortle, K.G. Fisheries of the Mekong River Basin. In The Mekong: Biophysical Environment of an International River Basin; Elsevier: Amsterdam, the Netherlands, 2009; pp. 197-249.

15. Dugan, P.J.; Barlow, C.; Agostinho, A.A.; Baran, E.; Cada, G.F.; Chen, D.; Cowx, I.G.; Ferguson, J.W.; Jutagate, T.; Mallen-Cooper, M.; et al. Fish migration, dams, and loss of ecosystem services in the Mekong basin. Ambio 2010, 39, 344-348.

16. Reuss, M. Is it time to resurrect the Harvard Water Program? J. Water Resour. Plan. Manag. 2003, 129, 357-360. [CrossRef]

17. Piman, T.; Cochrane, T.A.; Arias, M.E. Effect of proposed large dams on water flows and hydropower production in the Sekong, Sesan and Srepok rivers of the Mekong Basin. River Res. Appl. 2016, 32, 2095-2108. [CrossRef]

18. Baran, E. Fish migration triggers in the Lower Mekong Basin and other freshwater tropical systems. MRC Tech. Paper 2006, 14, 56.

19. Baran, E.; Samadee, S.; Teoh, S.J.; Tran, T.C. Fish and fisheries in the Sekong, Sesan and Srepok basins (3S rivers, Mekong watershed), with special reference to the Sesan River; International Centre for Environmental Management (ICEM): Hanoi, Vietnam, 2013; pp. 1-74.

20. Arias, M.E.; Cochrane, T.A.; Kummu, M.; Lauri, H.; Holtgrieve, G.W.; Koponen, J.; Piman, T. Impacts of hydropower and climate change on drivers of ecological productivity of Southeast Asia's most important wetland. Ecol. Modell. 2014, 272, 252-263. [CrossRef]

21. Hecht, J.S.; Lacombe, G.; Arias, M.E.; Dang, T.D.; Piman, T. Hydropower dams of the Mekong River basin: A review of their hydrological impacts. J. Hydrol. 2019, 568, 285-300. [CrossRef]

22. Wild, T.B.; Reed, P.M.; Loucks, D.P.; Mallen-Cooper, M.; Jensen, E.D. Balancing hydropower development and ecological impacts in the Mekong: Tradeoffs for sambor mega dam. J. Water Resour. Plan. Manag. 2019, 145, 5018019. [CrossRef]

23. Kondolf, G.M.; Rubin, Z.K.; Minear, J.T. Dams on the Mekong: Cumulative sediment starvation. Water Resour. Res. 2014, 50, 5158-5169. [CrossRef] 
24. Kummu, M.; Lu, X.; Wang, J.J.; Varis, O. Basin-wide sediment trapping efficiency of emerging reservoirs along the Mekong. Geomorphology 2010, 119, 181-197. [CrossRef]

25. Baran, E.; So, N.; Degen, P.; Chen, X.Y.; Starr, P. Updated information on fish and fisheries in the Mekong Basin. Catch Cult. 2013, 19, 24-25.

26. Barbarossa, V.; Schmitt, R.J.P.; Huijbregts, M.A.J.; Zarfl, C.; King, H.; Schipper, A.M. Impacts of current and future large dams on the geographic range connectivity of freshwater fish worldwide. Proc. Natl. Acad. Sci. USA 2020, 117, 3648-3655. [CrossRef] [PubMed]

27. Dudgeon, D. Large-scale hydrological changes in tropical Asia: Prospects for riverine biodiversity: The construction of large dams will have an impact on the biodiversity of tropical Asian rivers and their associated wetlands. Bioscience 2000, 50, 793-806. [CrossRef]

28. Thul, P.C. Cambodia halts mainstream Mekong River dam plans for 10 years, official says. Reuters, 18 March 2020.

29. Mekong Region Futures Institute. Dataset on the Dams of the Greater Mekong; Mekong Region Futures Institute: Bangkok, Thailand, 2020.

30. Japan International Cooperation Agency. The Master Plan Study on Rural Electrification by Renewable Energy in the Kingdom of Cambodia; Japan International Cooperation Agency: Tokyo, Japan, 2006.

31. Japan International Cooperation Agency. Data Collection Survey on Water Resources Management in Central Highlands; Japan International Cooperation Agency: Tokyo, Japan, 2018.

32. Allaire, J.J.; Gandrud, C.; Russell, K.; Yetman, C.J. networkD3: D3 JavaScript Network Graphs from R. R Package Version 0.42017.

33. Mekong River Commission. Basin Development Plan Programme, Phase 2: Assessment of Basin-wide Development Scenarios. Mekong River Comm. 2011, 1, 1-119.

34. Grill, G.; Dallaire, C.O.; Chouinard, E.F.; Sindorf, N.; Lehner, B. Development of new indicators to evaluate river fragmentation and flow regulation at large scales: A case study for the Mekong River Basin. Ecol. Indic. 2014, 45, 148-159. [CrossRef]

35. Orr, S.; Pittock, J.; Chapagain, A.; Dumaresq, D. Dams on the Mekong River: Lost fish protein and the implications for land and water resources. Glob. Environ. Chang. 2012, 22, 925-932. [CrossRef]

36. Shaad, K.; Souter, N.J.; Farrell, T.; Vollmer, D.; Regan, H.M. Evaluating the sensitivity of dendritic connectivity to fish pass efficiency for the Sesan, Srepok and Sekong tributaries of the Lower Mekong. Ecol. Indic. 2018, 91, 570-574. [CrossRef]

37. Ou, C.; Winemiller, K.O. Seasonal hydrology shifts production sources supporting fishes in rivers of the Lower Mekong Basin. Can. J. Fish. Aquat. Sci. 2016, 73, 1342-1362. [CrossRef]

38. Arias, M.E.; Piman, T.; Lauri, H.; Cochrane, T.A.; Kummu, M. Dams on Mekong tributaries as significant contributors of hydrological alterations to the Tonle Sap Floodplain in Cambodia. Hydrol. Earth Syst. Sci. 2014, 18, 5303-5315. [CrossRef]

39. Arias, M.E.; Cochrane, T.A.; Piman, T.; Kummu, M.; Caruso, B.S.; Killeen, T.J. Quantifying changes in flooding and habitats in the Tonle Sap Lake (Cambodia) caused by water infrastructure development and climate change in the Mekong Basin. J. Environ. Manag. 2012, 112, 53-66. [CrossRef]

40. Cochrane, T.A.; Arias, M.E.; Teasley, R.L.; Killeen, T.J. Simulated changes in water flows of the Mekong River from potential dam development and operations on the Se San and Sre Pok tributaries. In Proceedings of the IWA World Water Congress and Exhibition, Montreal, QC, Canada, 19-24 September 2010; pp. 19-24.

41. Golden, C.D.; Shapero, A.; Vaitla, B.; Smith, M.R.; Myers, S.S.; Stebbins, E.A.; Gephart, J.A. Impacts of Hydropower Development on Fisheries and Human Nutrition in the Lower Mekong. Front. Sustain. Food Syst. 2019, 3, 93. [CrossRef]

42. Yu, W.; Kim, Y.; Lee, D.; Lee, G. Hydrological assessment of basin development scenarios: Impacts on the Tonle Sap Lake in Cambodia. Quat. Int. 2019, 503, 115-127. [CrossRef]

43. Baird, I.; Mean, M. Sesan river fisheries monitoring in Ratanakiri province, northeast Cambodia: Before and after the construction of the Yali Falls dam in the Central Highlands of Viet Nam. In $3 S$ Rivers Protection Network and the Global Association for People and the Environment; 3S Rivers Protection Network: Ban Lung, Cambodia, 2005; p. 92.

44. Räsänen, T.A.; Varis, O.; Scherer, L.; Kummu, M. Greenhouse gas emissions of hydropower in the Mekong River Basin. Environ. Res. Lett. 2018, 13, 34030. [CrossRef]

45. Sievert, C. Interactive Web-Based Data Visualization with R, Plotly, and Shiny; Chapman and Hall/CRC: Boca Raton, FL, USA, 2020.

46. Dallaire, C.O.; Lehner, B.; Sayre, R.; Thieme, M. A multidisciplinary framework to derive global river reach classifications at high spatial resolution. Environ. Res. Lett. 2019, 14, 24003. [CrossRef]

47. Jager, H.I.; Efroymson, R.A.; Opperman, J.J.; Kelly, M.R. Spatial design principles for sustainable hydropower development in river basins. Renew. Sustain. Energy Rev. 2015, 45, 808-816. [CrossRef]

48. Piman, T.; Cochrane, T.A.; Arias, M.E.; Green, A.; Dat, N.D. Assessment of flow changes from hydropower development and operations in Sekong, Sesan, and Srepok rivers of the Mekong basin. J. Water Resour. Plan. Manag. 2013, 139, 723-732. [CrossRef]

49. Duc, N.A.; Nguyen, L.T.; Thai, T.H.; Khan, A.; Rautenstrauch, K.; Schmidt, C. Assessing cumulative impacts of the proposed Lower Mekong Basin hydropower cascade on the Mekong River floodplains and Delta-Overview of integrated modeling methods and results. J. Hydrol. 2020, 581, 122511.

50. Annandale, G.; Golder Associates. Technical Memorandum on Options for Sediment Passage through Lower Se San 2 Dam; Ministry of Industry, Mines, and Energy: Phnom Penh, Cambodia; Ministry of Water Resources and Meteorology: Phnom Penh, Cambodia; Natural Heritage Institute: San Francisco, CA, USA, 2013.

51. Sabo, J.L.; Ruhi, A.; Holtgrieve, G.W.; Elliott, V.; Arias, M.E.; Ngor, P.B.; Räsänen, T.A.; Nam, S. Designing river flows to improve food security futures in the Lower Mekong Basin. Science 2017, 358, eaao1053. [CrossRef] 
52. Wild, T.B.; Loucks, D.P.; Annandale, G.W.; Kaini, P. Maintaining sediment flows through hydropower dams in the Mekong River Basin. J. Water Resour. Plan. Manag. 2016, 142, 5015004. [CrossRef]

53. Ngo, L.A.; Masih, I.; Jiang, Y.; Douven, W. Impact of reservoir operation and climate change on the hydrological regime of the Sesan and Srepok Rivers in the Lower Mekong Basin. Clim. Change 2018, 149, 107-119. [CrossRef]

54. Natural Heritage Institute. Sambor Hydropower Dam Alternatives Assessment Final Report; Natural Heritage Institute: San Francisco, CA, USA, 2017.

55. Räsänen, T.A.; Joffre, O.M.; Someth, P.; Thanh, C.T.; Keskinen, M.; Kummu, M. Model-based assessment of water, food, and energy trade-offs in a cascade of multipurpose reservoirs: Case study of the Sesan Tributary of the Mekong River. J. Water Resour. Plan. Manag. 2015, 141, 5014007. [CrossRef]

56. Wells-Dang, A.; Soe, K.N.; Inthakoun, L.; Tola, P.; Socheat, P.; Van, T.T.; Chabada, A.; Youttananukorn, W. A political economy of environmental impact assessment in the Mekong Region. Water Altern. 2016, 9, 33-55.

57. Baran, E.; Samadee, S.; Teoh, S.J.; Tran, T.C. Fish and Fisheries in the Sesan River Basin: MK3 Catchment Baseline, Fisheries Section; WorldFish Center: Phnom Penh, Cambodia; Penang, Malaysia; ICEM: Hanoi, Vietnam, 2011; pp. 1-61.

58. Kraft, M.; Rosenberg, D.E.; Null, S.E. Prioritizing Stream Barrier Removal to Maximize Connected Aquatic Habitat and Minimize Water Scarcity. JAWRA J. Am. Water Resour. Assoc. 2019, 55, 382-400. [CrossRef]

59. Pokhrel, Y.; Burbano, M.; Roush, J.; Kang, H.; Sridhar, V.; Hyndman, D.W. A review of the integrated effects of changing climate, land use, and dams on Mekong river hydrology. Water 2018, 10, 266. [CrossRef]

60. Jensen, C.B. A flood of models: Mekong ecologies of comparison. Soc. Stud. Sci. 2020, 50, 76-93. [CrossRef] [PubMed]

61. Johnston, R.; Kummu, M. Water resource models in the Mekong Basin: A review. Water Resour. Manag. 2012, 26, 429-455. [CrossRef]

62. Piman, T.; Lennaerts, T.; Southalack, P. Assessment of hydrological changes in the lower Mekong Basin from Basin-Wide development scenarios. Hydrol. Process. 2013, 27, 2115-2125. [CrossRef]

63. Cochrane, T.A.; Arias, M.E.; Piman, T. Historical impact of water infrastructure on water levels of the Mekong River and the Tonle Sap system. Hydrol. Earth Syst. Sci. 2014, 18, 4529-4541. [CrossRef]

64. Stagge, J.H.; Rosenberg, D.E.; Abdallah, A.M.; Akbar, H.; Attallah, N.A.; James, R. Assessing data availability and research reproducibility in hydrology and water resources. Sci. Data 2019, 6, 190030. [CrossRef] [PubMed]

65. Jager, H.I.; Smith, B.T. Sustainable reservoir operation: Can we generate hydropower and preserve ecosystem values? River Res. Appl. 2008, 24, 340-352. [CrossRef]

66. IPCC (Intergovernmental Panel on Climate Change). Summary for Policymakers. In Climate Change 2014: Mitigation of Climate Change; Edenhofer, O., Pichs-Madruga, R., Sokona, Y., Farahani, E., Kadner, S., Seyboth, K., Adler, A., Baum, I., Brunner, S., Eickemeier, P., et al., Eds.; Cambridge University Press: Cambridge, UK, 2014.

67. Federer, L.M.; Belter, C.W.; Joubert, D.J.; Livinski, A.; Lu, Y.L.; Snyders, L.N.; Thompson, H. Data sharing in PLoS ONE: An analysis of data availability statements. PLOS ONE 2018, 13, e0194768. [CrossRef] [PubMed]

68. Graf, W.L. Dam nation: A geographic census of American dams and their large-scale hydrologic impacts. Water Resour. Res. 1999, 35, 1305. [CrossRef]

69. Moran, E.F.; Lopez, M.C.; Moore, N.; Müller, N.; Hyndman, D.W. Sustainable hydropower in the 21st century. Proc. Natl. Acad. Sci. USA 2018, 115, 11891-11898. [CrossRef] [PubMed]

70. Hanemann, M.; Dyckman, C. The San Francisco Bay-Delta: A failure of decision-making capacity. Environ. Sci. Policy 2009, 12, 710-725. [CrossRef]

71. Elmore, L.R.; Null, S.E.; Mouzon, N.R. Effects of environmental water transfers on stream temperatures. River Res. Appl. 2016, 32, 1415-1427. [CrossRef]

72. Null, S.E. Water Supply Reliability Tradeoffs between Removing Reservoir Storage and Improving Water Conveyance in California. J. Am. Water Resour. Assoc. 2016, 52, 350-366. [CrossRef]

73. Null, S.E.; Medellin-Azuara, J.; Escriva-Bou, A.; Lent, M.; Lund, J.R. Optimizing the dammed: Water supply losses and fish habitat gains from dam removal in California. J. Environ. Manag. 2014, 136, 121-131. [CrossRef]

74. Campbell, I.; Barlow, C. Hydropower Development and the Loss of Fisheries in the Mekong River Basin. Front. Environ. Sci. 2020, 8, 200. [CrossRef]

75. Ansar, A.; Flyvbjerg, B.; Budzier, A.; Lunn, D. Should we build more large dams? The actual costs of hydropower megaproject development. Energy Policy 2014, 69, 43-56. [CrossRef]

76. Chowdhury, A.F.M.K.; Dang, T.D.; Bagchi, A.; Galelli, S. Expected Benefits of Laos' Hydropower Development Curbed by Hydroclimatic Variability and Limited Transmission Capacity: Opportunities to Reform. J. Water Resour. Plan. Manag. 2020, 146, 5020019. [CrossRef]

77. Kummu, M.; Sarkkula, J. Impact of the Mekong River flow alteration on the Tonle Sap flood pulse. AMBIO A J. Hum. Environ. 2008, 37, 185-192. [CrossRef]

78. Ngor, P.B.; McCann, K.S.; Grenouillet, G.; So, N.; McMeans, B.C.; Fraser, E.; Lek, S. Evidence of indiscriminate fishing effects in one of the world's largest inland fisheries. Sci. Rep. 2018, 8, 1-12. [CrossRef] [PubMed]

79. Chan, B.; Ngor, P.B.; Hogan, Z.S.; So, N.; Brosse, S.; Lek, S. Temporal Dynamics of Fish Assemblages as a Reflection of Policy Shift from Fishing Concession to Co-Management in One of the World's Largest Tropical Flood Pulse Fisheries. Water 2020, $12,2974$. [CrossRef] 
80. Chea, R.; Grenouillet, G.; Lek, S. Evidence of water quality degradation in lower Mekong basin revealed by self-organizing map. PLOS ONE 2016, 11, e0145527. [CrossRef] [PubMed]

81. Oeurng, C.; Cochrane, T.A.; Arias, M.E.; Shrestha, B.; Piman, T. Assessment of changes in riverine nitrate in the Sesan, Srepok and Sekong tributaries of the Lower Mekong River Basin. J. Hydrol. Reg. Stud. 2016, 8, 95-111. [CrossRef]

82. Channa, P.; Sereyvuth, H.; Bunwath, T.A.N.S.; Kimsan, L.O.R.; Somany, P. Population Monitoring of the Critically Endangered Mekong River Dolphin Based on Mark-Resight, Cambodia; WWF-Cambodia Technical Report; WWF-Cambodia: Phnom Penh, Cambodia, 2015; pp. 1-22.

83. Hogan, Z.S.; Moyle, P.B.; May, B.; Zanden, M.J.V.; Baird, I.G. The Imperiled Giants of the Mekong: Ecologists struggle to understand-and protect-Southeat Asia's large migratory catfish. Am. Sci. 2004, 92, 228-237.

84. Lohani, S.; Dilts, T.E.; Weisberg, P.J.; Null, S.E.; Hogan, Z.S. Rapidly accelerating deforestation in Cambodia's Mekong River Basin: A comparative analysis of spatial patterns and drivers. Water 2020, 12, 2191. [CrossRef]

85. Thilakarathne, M.; Sridhar, V. Characterization of future drought conditions in the Lower Mekong River Basin. Weather Clim. Extrem. 2017, 17, 47-58. [CrossRef]

86. Yang, J.; Yang, Y.C.E.; Chang, J.; Zhang, J.; Yao, J. Impact of dam development and climate change on hydroecological conditions and natural hazard risk in the Mekong River Basin. J. Hydrol. 2019, 579, 124177. [CrossRef]

87. Yoshida, Y.; Lee, H.S.; Trung, B.H.; Tran, H.D.; Lall, M.K.; Kakar, K.; Xuan, T.D. Impacts of Mainstream Hydropower Dams on Fisheries and Agriculture in Lower Mekong Basin. Sustainability 2020, 12, 2408. [CrossRef]

88. Trisurat, Y.; Aekakkararungroj, A.; Ma, H.; Johnston, J.M. Basin-wide impacts of climate change on ecosystem services in the Lower Mekong Basin. Ecol. Res. 2018, 33, 73-86. [CrossRef] [PubMed]

89. Null, S.; Farshid, A.; Goodrum, G.; Gray, C.; Lohani, S.; Morrisett, C.; Prudencio, L.; Sor, R. Environmental Tradeoffs of Hydropower Dams in the Sekong, Sesan, and Srepok (3S) Rivers of the Lower Mekong Basin, HydroShare. 2020. Available online: http:/ / www.hydroshare.org/resource/5e57b81fa6994fc3b63f6b7d5dc54cf0 (accessed on 29 December 2020).

90. Null, S.; Farshid, A.; Goodrum, G.; Gray, C.; Lohani, S.; Morrisett, C.; Prudencio, L.; Sor, R. Environmental tradeoffs of hydropower dams in the Sekong, Sesan, and Srepok (3S) Rivers of the Lower Mekong Basin, Mekong Water. 2020. Available online: http:/ / data.mekongwater.org/resource/3ce6587a4c424e748498490e141a1077 (accessed on 29 December 2020). 